\title{
Singapore's Poverty Reduction Effectiveness Assessment for ASEAN
}

\author{
Ning Liu ${ }^{1, a, *, \dagger}$, Peijie Wang ${ }^{2, \text { b, }{ }^{*}, \dagger}$, Miaoqi Zhang ${ }^{3, c, ~}, \dagger$ \\ ${ }^{1}$ Guangdong University of Foreign Studies, Guangzhou, China \\ ${ }^{2}$ Sophia University, Tokyo, Japan \\ ${ }^{3}$ Shanghai International Studies University, Shanghai, China \\ "Corresponding author email: ${ }^{a} 20180501994 @ g d u f$ s.edu.cn, ${ }^{b}$ p-wang-7b2@eagle.sohpia.ac.jp, \\ cJackson626@foxmail.com, \\ These authors contributed equally.
}

\begin{abstract}
As a regional organization in Southeast Asia, ASEAN is the fifth-largest economy globally, the fourth largest import and export trading region in the world, and one of the main areas for developing countries to absorb FDI. However, the extremely unbalanced economic development of ASEAN countries seriously hinders the integration of ASEAN. As the most developed country in Asia, Singapore plays a pivotal role in ASEAN. This article is intended to build a logical relationship and an empirical analysis with qualitative research to explore Singapore's contribution to ASEAN poverty reduction. Based on literature review and descriptive data from the websites of ASEAN and Singapore's government, this article compares the poverty rate of ASEAN countries before and after Singapore's economic assistance. The following conclusions are drawn according to SDGs standards. Although Singapore's economic aid has not succeeded in achieving complete poverty reduction in ASEAN, these projects bring benefits to ASEAN and bring considerable economic power and political influence to Singapore itself. Therefore, Singapore's poverty reduction projects for ASEAN will continue to flourish in the future. Based on the existing literature and data, the research of this article makes a specific analysis of the example of ASEAN, showing that FDI is not the decisive reason for poverty reduction. That effectively breaks through the theoretical assumptions and shows the complexity and uncertain variables of the real situation in international relations research.
\end{abstract}

Keywords: ASEAN, Singapore, FDI, Poverty Reduction.

\section{INTRODUCTION}

On August 8, 1967, ASEAN was established as a regional organization in Southeast Asia, whose initiators were Indonesia, Malaysia, the Philippines, Singapore, and Thailand, which also became ASEAN-6. Brunei joined ASEAN in 1984, Vietnam joined ASEAN in 1995, Laos and Myanmar joined ASEAN in 1997, and Cambodia joined ASEAN in 1999. At this point, ASEAN became a regional organization containing 10 Southeast Asian countries. The influence of ASEAN is growing in economic, political, and cultural aspects. Along with the expansion of ASEAN, the economic, political, and cultural unity within ASEAN has been increasingly emphasized. In the first article of the ASEAN objectives, the promotion of regional economic growth and social progress is clearly stated [1]. Increasing intra-ASEAN trade activities is an important part of promoting ASEAN integration.

Yet, the gap between rich and poor within ASEAN affects ASEAN's integration. We can't ignore that ASEAN has diverse member states, containing per capita ranging from about $\$ 1.390$ in Cambodia, a lower-middleincome developing economy, to $\$ 57,713$ in Singapore, a high-income advanced economy. The diversity in the economy also appears in ASEAN's preference for SDGs. In target 1.1 of SDGs, eradicating extreme poverty for all people everywhere, Singapore has a $0 \%$ poverty rate while Laos reaches over 15\% [2].

Becoming an independent state from Malaya since 1965, Singapore has earned great progress over the last decades with little natural resources and small land, which made it a highly developed country in Asia and the world. According to the UN's record, Singapore has the 
world's second-highest average GDP. Its success in economic development and its experience of anti-poverty provides a great model for developing countries. Its economic influence makes it an important country to help ASEAN countries develop their economies to narrow the gap between rich and poor.

Has Singapore contributed much to poverty reduction in Southeast Asia? How to evaluate Singapore's achievements for poverty reduction in ASEAN? This article uses data from SDGs to evaluate Singapore's contribution to poverty reduction in ASEAN member countries.

\section{LITERATURE REVIEW}

This section presents an overview of the literature on the linkage of foreign direct investment (FDI) and poverty reduction. According to Hossein and John [3], FDI plays a positive role in poverty reduction in the ASEAN region. They create a quantitative model, and with the help of the model, attribute poverty reduction to FDI with its impact on economic growth.

Van Der Sluis and Durowah [4] investigate the role of aid for trade (AFT) and foreign direct investment (FDI) in poverty reduction. Based on data for 91 developing countries and using fixed effects and random effects models, their empirical analysis indicates that AFT and FDI flows positively affect reducing poverty.

Ucal[5]conducts an empirical investigation into the relationship between FDI and poverty at the macropathway in developing countries. The author develops a data set and an econometric model. Results show a statistically significant relationship between FDI and poverty, and it is obvious that FDI reduces poverty in developing countries.

Moatari and Gaskari [6] analyze the relation between FDI and poverty in developing countries. Using the panel data regression model, the authors confirm that FDI effectively achieves poverty reduction in developing countries.

To examine the relationship between FDI inflows and poverty in selected African economies, Fowowe and Shuaibu [7], using the system generalized method of moments, indicate that FDI inflows have significantly contributed to poverty reduction in African countries. Besides, based on the result, the authors also conclude that interacting FDI with financial development significantly reduces poverty.

Secondly, there are a large number of empirical studies of the significant factors determining FDI. Based on the socio-economic development, Xaypanya, Rangkakulnuwat, and Paweenawat [8] divide the ASEAN countries into two groups, ASEAN3 (Cambodia, Laos, and Vietnam) and ASEAN5 (Indonesia, Malaysia, the Philippines, Thailand, and Singapore. In examining the panel data during 2000-2011 from the WB and the UNCTAD, they argue that determinants affect economic growth differently in the two groups. In the ASEAN3 countries, infrastructure facility, level of openness, and inflation on FDI inflow are significant effects, while in the ASEAN5, market size and infrastructure facility positively influence FDI.

Hoang and Bui [9] use data from six ASEAN countries (Vietnam, Indonesia, Malaysia, Philippines, Singapore, and Thailand) and detect close linkage between the market size, trade openness, quality infrastructure, human capital, labor productivity, and FDI inflows. Additionally, exchange rate policy, real interest rate, political risk, and corruption also positively affect FDI inflows.

Uttama [10] examines that in the case of the ASEAN region, FDI and economic integration have a significant impact on poverty reduction. He uses the spatial panel data model techniques to investigate the impacts of foreign FDI and spatial effects. Based on the result, there are several factors, for example, bilateral FDI, economic integration, GDP, foreign debt, and the spatial effect of FDI, that have positive relationships with poverty reduction.

Bhatt [11] estimates the empirical model for five countries (Indonesia, Malaysia, Philippines, Singapore, and Thailand) of ASEAN and finds that in Indonesia and Singapore, the size of the economy (GNI) influences FDI inflows positively. For Indonesia and Malaysia, the infrastructure plays an important role in attracting FDI. The exchange rate influences the FDI of Malaysia, and the openness of the economy has a close relation to attracting FDI for Indonesia. Pooled least method and fixed effect model are used to estimate this model for panel data of the ASEAN region.

Saini and Singhania [12] investigate FDI determinants based on panel data analysis using static and dynamic models (generalized moments of methods) for 20 countries ( 11 developed and 9 developing) over the period 2004-2013. The results showed that in a developing country, FDI shows a positive association for economic determinants (gross fixed capital formation (GFCF), trade openness, and efficiency variables).

According to $\mathrm{Ho}, \mathrm{Vo}$, and $\mathrm{Vu}$ [13], market size trade openness is a significant determinant of FDI inflows into ASEAN. They divide ASEAN member countries into ASEAN3 (Cambodia, Laos, and Vietnam) and ASEAN5 (Indonesia, Malaysia, Philippines, Thailand, Singapore) by the level of economic development and analyze by the panel ordinary least square estimation with the method of first differencing for the period between 1996 and 2016. The empirical results also support that FDI is positively related to market size and infrastructure facilities; negatively correlated to labor cost and trade openness in the ASEAN3 region. 
Using a panel data econometric model, Shahmoradi and Baghbanyan[14] estimate the determining factors of FDI inflows in developing countries throughout 19902007. Based on the results, the openness of the economy, market size, availability of labour force, ODA, mobile, technology, and internet influence the FDI inflows in developing countries positively. Moreover, they conclude that a high population rate has a negative effect on it.

Choa and Kim [15] examine the impact of financial development on FDI flow in host countries. They make panel data analysis based on a gravity FDI equation with bilateral FDI data from 34 OECD source countries to 146 host countries. The results suggest that the wellfunctioning finance market of source countries and a better accessible financial market of host countries positively affect FDI.

To investigate the determinants of FDI inflow in developing countries, Kumari and Sharma [16] use unbalanced panel data set from 1990-2012. They consider 20 developing countries from the whole of South, East, and South-East Asia. The estimation indicates that market size, trade openness, interest rate, and human capital affect FDI inflow positively.

To investigate the impact of the ASEAN-Korea FTA (AKFTA) on the national economy and poverty in Laos, $\mathrm{OH}$, and KYOPHILAVONG[17], use a standard Global Trade Analysis Project (GTAP) model. Foreign Direct Investment and trade facilitation are representative by AKFTA. They use four simulations: reducing tariff, improve trade facilitation, increasing FDI, and combination of three simulation scenarios and examine that the increase in FDI and the improvement of trade facilitation from AKFTA have influenced the macroeconomic variables positively: real GDP, welfare, household income, and trade terms and balance thus affect Laos.

In sum, most empirical studies indicate the significant effects of Foreign Direct Investment (FDI) and poverty reduction. The empirical analysis in this study is conducted under the specific hypotheses based on the literature review mentioned above.

\section{METHOD}

First of all, in the discussion of Singapore in the process of ASEAN economic aid and poverty reduction and Singapore's leadership in ASEAN, this article uses the method of qualitative research, collecting Singapore ASEAN economic aid to descriptive data, on the strength of the SDI input. It includes how Singapore and SDG accounted, trade exports growth, poverty reduction projects the change of the quantity, the economic growth rate of poor countries with the increase of Singapore's economic assistance, the proportion of local absolute population reduction, the trade volume of the country, the frequency of exchange visits by officials, and the absolute population proportion reported by the country, etc., are analyzed from the data. In this article, the change of Singapore's political status in ASEAN, the increase of Singapore's discourse power in ASEAN, the rise of ASEAN integration level, the change of Singapore's bilateral relations with the aided ASEAN countries, and the direct impact of Singapore's economic aid and poverty reduction projects on the economy of ASEAN countries are discussed. In addition, to enrich the qualitative research of this article and make the relationship between poverty reduction results in Singapore and Southeast Asia more clear, this article analyzes with more examples. It builds a clear, logical relationship based on the contributions made by previous literatures.

Meanwhile, this article uses the method of observation and comparative analysis, discusses the reality of ASEAN countries with the increase of Singapore's economic assistance, as well as the change of Singapore's status in ASEAN, to highlight Singapore's economic assistance to ASEAN, as well as the benefits and its impact, etc.

\section{DATA ANALYZE}

Singapore's Foreign Direct Investment inward to ASEAN

From the ASEAN data[18], we can get the percentage and volume of external direct investment within ASEAN by ASEAN member countries. 2010, Singapore's direct investment within ASEAN was US\$8,931.36 million, while the total investment of the whole ASEAN countries was US\$15,520.86 million. Singapore's investment accounted for $57.5 \%$ of this total. $57.5 \%$ of this total. From 2011 to 2020, Singapore's FDI amounts to $80.2 \%$, $41.0 \%, 71.9 \%, 70.9 \%, 65.8 \%, 61.8 \%, 67.5 \%, 64.8 \%$, and $70.6 \%$ of the entire ASEAN respectively. Singapore's share of FDI within ASEAN has been $60 \%$ and more than $60 \%$ of ASEAN for ten years except for 2012. In terms of the amount of investment, Singapore's investment amount has almost always been on the rise, with a low of US\$8,931.36 million in 2010 to a high of US\$17,486.61 million in 2017, a 1.96-fold increase. Thus, Singapore's investment in ASEAN member countries shows a trend of the largest share of the total amount, the largest investment, and the increase in the amount of investment.

Next, we look specifically at Singapore's direct investment in other ASEAN member countries. According to Singapore government data[19], Singapore has invested in ASEAN member countries (Indonesia, Malaysia, Myanmar, Philippines, Thailand, Vietnam, Brunei) other than Laos and Cambodia from 1994 to 2019. Its investments have also shown a steady upward trend and a steady increase in the total amount. Singapore's investment in Brunei Darussalam grew from \$128.5 million from 1994 to 2019 to $\$ 194.9$ million in 2009 at the pace of $51.6 \%$. It peaked at $\$ 268.2$ million in 2015 . 
Singapore's investment in Indonesia, which was only $\$ 2359.9$ million in 1994, doubled 27.6 times to $\$ 65,233.6$ million in 2019. Singapore's investment in Malaysia went from $\$ 8,182.3$ million in 1994 to $\$ 54,293.6$ million in 2019, a $6.6 \%$ increase. Singapore's investment in Myanmar has doubled 37.9 times since 1998 from \$229.9 million to $\$ 8732.2$ million in 2019. Singapore's investment in the Philippines changed from $\$ 445.2$ million in 1994 to $\$ 8848.9$ million in 2019, a 19.8-fold increase. Singapore's investment in Thailand has doubled 29 times from $\$ 1,073.6$ million in 1994 to $\$ 31,135.4$ million in 2019. Singapore's investment in Vietnam has doubled 70 times from $\$ 172$ million in 1994 to $\$ 12,199.8$ million in 2019.

In terms of the scale of investment, Singapore's investment in Indonesia and Malaysia is the largest; in 1994, Singapore's investment in Indonesia was US\$2359.9 million, accounting for $18.9 \%$ of all Southeast Asian member countries, and was in second place. In 2019, Singapore invested US\$65,233.6 million in Indonesia, accounting for $35.4 \%$ of the ASEAN countries, making it Singapore's top intra-ASEAN investor. In 1994, Singapore's investment in Malaysia amounted to US\$8,182.3 million, accounting for $65.8 \%$ of entire Southeast Asia, ranking first. 2014, Singapore's investment in Malaysia amounted to US\$54,293.6 million, accounting for $29.4 \%$ of Southeast Asia, making it Singapore's second-largest investor. Singapore's lowest investments in ASEAN member countries were in Myanmar, the Philippines, and Vietnam.

SDGs Target1.1, Eradicate Extreme Poverty, measured at the international poverty line, with a standard of living below $\$ 1.25$ per day. From the UN data[20], we can get the variation of this indicator in Southeast Asian countries. In Indonesia, the index was 59\% in the 1990s and increased to $67 \%$ in 1998 , but from the 2000 s onwards, the indicator has been declining continuously, reaching $16 \%$ in 2010 and 5\% in 2018. On the other hand, Malaysia has not changed much in this indicator, which was $0 \%$ in 1997 . Thailand, where the indicator was $9 \%$ in 1990, has been showing a declining trend, and in 2007 the indicator became $0 \%$.

Myanmar's indicator was $6 \%$ in 2015 and became $2 \%$ in 2017. The Philippines had $14 \%$ in $2000,15 \%$ in 2006 , and in 2015 the indicator became 6\%. Vietnam had 53\% on the indicator in 1992, and by 2010 , the indicator dropped to single digits and became $2 \%$ in 2018.

Target1.2 aims to eliminate half of the men, women, and children living below the nationally defined poverty line by 2030 . The indicator used to judge this target is the national poverty line. The data[21] shows that there is still a big problem in ASEAN countries under the national poverty line. Although Cambodia's poverty rate was only $6.4 \%$ in urban areas in 2012, a significant decrease from $28.5 \%$ in 2003 still had $20.8 \%$ in rural areas and $17.7 \%$ in all regions in 2012. In Laos, the poverty rate in urban areas was $23.4 \%$ in 2012 , while the rural population below the poverty line was $28.6 \%$.

Vietnam had $9.8 \%$ of the population living below the poverty line, and in $2014,18.6 \%$ of the population was below the poverty line, and 3.8\% was urban. Myanmar's poverty rate was $32.1 \%$ in 2015 . The Philippines, on the other hand, was $21.6 \%$ in the same year, not a significant decrease from $24.9 \%$ in 2003 . The population living below the poverty line in Indonesia was $10.6 \%$, and in Malaysia, the rural population below the poverty line was $1.6 \%$ in 2014 , compared to $1.6 \%$ in urban areas.

From the above data, we can see that the amount of Singapore's investment in various ASEAN countries has been on an upward trend. Singapore's investment in Indonesia, Malaysia, and Thailand has been among the top three in Southeast Asia for years. The poverty reduction situation in these three countries is very different. Indonesia has successfully reduced poverty, with the international poverty line going from 59\% in 1990 to $5 \%$ in 2019 . But the percentage of its national population below the poverty line was still 10.9 percent in 2016. Although large, Singapore's FDI investment in Indonesia has not been very effective in helping its population below the national poverty line. Malaysia, Singapore's second-largest investor in ASEAN, has had a relatively low percentage of people below the international poverty line since the 1990s. Its share of the national poverty line population in rural areas has also declined from $11.9 \%$ in 2004 to $1.6 \%$. While already at $0 \%$ of the population below the international poverty line, Thailand still has $13.9 \%$ of its population below the national poverty line in rural areas.

Myanmar, on the other hand, Vietnam is at the lower end of Singapore's investment locations. Although Singapore's FDI to Myanmar has risen 37 times, the total is small and started late. But Myanmar's share of the population below the international poverty line became $2 \%$ in 2017, according to the SDGs. Singapore's total investment in Vietnam surpassed that of the Philippines in 2014. The proportion of people below the international poverty line in Vietnam also went from $53 \%$ to $2 \%$. Thus, Singapore's investment in the relatively backward countries of ASEAN has contributed to their economic development. However, the percentage of people below the national poverty line remains at $9.8 \%$ in 2016 .

Singapore's investments have led to more frequent economic trade among the countries and a significant reduction in the proportion of people below the international poverty line. However, in terms of the national poverty line indicator, except for Malaysia, a significant proportion of the population is below this standard.

Although Singapore is actively engaged in ASEAN economic and trade activities to promote ASEAN integration, the focus of Singapore's economic and trade 
activities is not Southeast Asia. 2019 Singapore's total worldwide investment was $\$ 934,738.4$ million, with Asia accounting for $\$ 501,339.6$, while Singapore's total investment in China was $\$ 147,014.5$ million, a difference of only $\$ 37,413.9$ million from ASEAN's \$184,438.4 million. The amount of investment in China is more than any individual country within ASEAN.

\subsection{Case: Initiative for ASEAN Integration}

This project is one of Singapore's assistance projects to ASEAN, which was established during Singapore's ASEAN chairmanship in 2000. The aim is to bridge the development gap between the original ASEAN-6 member countries and the four relatively late-stage countries of Cambodia, Myanmar, Laos, and Vietnam (CMLV) that joined later. Work Plan 1 (2002-2008) focused on the four CMLV countries. Work Plan2 (20092015) is based on ASEAN's target blueprint, with different projects established. In Work Plan2, as of 2010, Singapore led 24 projects, the first in all ASEAN, accounting for $43 \%$ of the 55 projects. Its fund is US\$1034,459 million[22].

Singapore is an active contributor to IAI and has pledged a total of $\$ 170$ million now. Under the IAI, Singapore established training centers in Cambodia, Laos, Myanmar, and Vietnam to help develop activities and give humanitarian assistance in Cambodia, Laos, Myanmar, and Vietnam. In 2018, those centers were rebranded as Singapore Cooperation Centers (SCCs)[23] to support the expansion of capacity-building activities in Cambodia, Laos, Myanmar, and Vietnam. SCCs also work with other partner countries, NGOs, and private sectors.

From a GDP perspective, the disparity within ASEAN remains huge. In 2019 Singapore's GDP per capita was US\$654,232.9[24], while Cambodia's was only US\$1,663.8. While ASEAN has a GDP per capita of 4818.8 and ASEAN-6 has a GDP per capita of 5780.2. CLMV GDP per capita is only $\$ 2149.7$, a difference of $\$ 3631$.

Singapore cannot be said to have succeeded in achieving poverty reduction through investment. On the contrary, Singapore's investments in external regions have become increasingly large with the integration of ASEAN. The development of ASEAN has allowed Singapore to gain more economic value while gaining influence within the region. But the economic development gap between countries within ASEAN will remain a challenge for ASEAN integration. Singapore understands that ASEAN is of great interest to it, so efforts to alleviate poverty for coming to Singapore will also continue.

\section{CONCLUSION}

At the beginning of this article, the authors introduce the existing literature on the relationship between FDI and poverty reduction effect and the model to illustrate the close relationship between FDI and poverty reduction. In the section of data analysis, the authors respectively list Singapore's FDI for ASEAN as a whole in recent years and the rest countries of ASEAN, the information on the data of its growth rate and in accordance with Singapore has carried on the arrangement to the various countries' direct investment amount. To demonstrate the relationship between Singapore's FDI and the poverty reduction achievements of ASEAN countries, the article also uses two poverty indicators of the United Nations: the international poverty line and the national poverty line. Available data indicate that most countries receiving Singapore's economic assistance have achieved significant improvements on the international poverty line. However, except for Malaysia, a significant proportion of the population falls below this standard when it comes to national poverty line indicators. On top of that, the gap between ASEAN countries, in terms of GDP, remains huge.

It is not difficult to find that although Singapore has provided large-scale economic assistance to ASEAN, It has not fully achieved the objectives of Singapore's assistance projects to ASEAN. On the contrary, the development of ASEAN and its economic activities with Singapore has enabled Singapore to obtain considerable economic benefits and political influence. Therefore, no matter from the perspective of the development needs of ASEAN or Singapore, Singapore's assistance projects to ASEAN will not be terminated.

This article combines a great number of available materials and abundant data to visually illustrate the FDI situation and the development of Singapore's assistance projects to ASEAN. The content of this paper is detailed and has special reference value. However, due to the lack of knowledge reserve and the inadequate grasp of quantitative research tools and the existence of complex influencing factors and huge variables in this research field, there is room for improvement in the quantitative analysis part and the control of other variables.

\section{REFERENCES}

[1] ASEAN, "Overview", Accessed May 30,2021. https://asean.org/asean/about-asean/overview/

[2] ASEANStatsDataPortal, Flows of Inward Foreign Direct Investment (FDI) into ASEAN by Source Country (in million US\$), https://data.aseanstats.org/fdi-by-hosts-and-sources

[3] Jalilian, Hossein, and John Weiss. "Foreign direct investment and poverty in the ASEAN region" 
ASEAN Economic Bulletin 19, no. 3 (2002): 23153. https://doi.org/10.1355/AE19-3A

[4] Van Der Sluis, E., and O., Durowah. "Aid for Trade and Foreign Direct Investment: Effects on Poverty Reduction," 2018 Conference, July 28-August 2, 2018, Vancouver, British Columbia, International Association of Agricultural Economists. https://doi.org/10.22004/ag.econ.277307

[5] Ucal, Meltem Şengün. "Panel Data Analysis of Foreign Direct Investment and Poverty from the Perspective of Developing Countries" 2nd World Conference on Business, Economics and Management 109 (2014): 1101-05. https://doi.org/10.1016/j.sbspro.2013.12.594

[6] Moatari, Babak, and Dr. Reyhaneh Gaskari. "The relationship between foreign direct investment and poverty reduction in developing countries." INTERNATIONAL JOURNAL OF HUMANITIES AND CULTURAL STUDIES (2016): 2645-51.

[7] Fowowe, Babajide, and Mohammed I. Shuaibu. "Is foreign Direct Investment Good for the Poor: New Evidence from African Countries" Economic Change and Restructuring 47 (2014): 321-39. https://doi.org/10.1007/s10644-014-9152-4

[8] Xaypanya, P., P. Rangkakulnuwat and S.W. Paweenawat. "The determinants of foreign direct investment in ASEAN: The first differencing panel data analysis " International Journal of Social Economics 42, no. 3(2015): 239-50. https://doi.org/10.1108/IJSE-10-2013-0238

[9] Hong Hiep Hoang and Hung Bui, Duc. "Determinants of foreign direct investment in ASEAN: A panel approach" Management Science $\begin{array}{llll}\text { Letters } & 5 & \text { (2015): } & \text { 213-22. }\end{array}$ https://doi.org/10.5267/j.msl.2014.12.015

[10] Uttama, Nathapornpan Piyaareekul. "Foreign Direct Investment and the Poverty Reduction Nexus in Southeast Asia." In Economic Studies in Inequality, Social Exclusion and Well-Being, edited by Heshmati A., Maasoumi E., Wan G., 281-98. Singapore: $\quad$ Springer, 2015. https://doi.org/10.1007/978-981-287-420-7_15

[11] Bhatt, Padmanabha Ramachandra. "Determinants of Foreign Direct Investment in ASEAN" Foreign Trade Review 43 (2008):21-51. https://doi.org/10.1177/0015732515080302

[12] Saini, Neha, and Monica Singhania. "Determinants of FDI in developed and developing countries: a quantitative analysis using GMM" Journal of Economic Studies 45 (2018): 348-82. https://doi.org/10.1108/JES-07-2016-0138
[13] Ho Thanh Tri, Thi Nga, Vo, and Hoang Duong, Vu. "The determinants of foreign direct investment in ASEAN: New evidence from financial integration factor" Business and Economic Horizons 15 (2019): 292-303. https://doi.org/10.22004/ag.econ.301149

[14] Shahmoradi, Behrooz, and Mostafa Baghbanya. "Determinants of Foreign Direct Investment in Developing Countries: A Panel Data Analysis" Asian Economic and Financial Review 1 (2011): 4956. https://doi.org/10.1109/ICEE.2012.1135

[15] Choa, Jung-Whan, and Tae-Hwang Kim. "The Effects of Financial Development on Foreign Direct Investment" Korea Trade Review 45, no. 4 (2020): 195-205.

https://data.doi.or.kr/10.22659/KTRA.2020.45.4.19

[16] Kumari, Reenu, and Anil Kumar Sharma. "Determinants of Foreign Direct Investment in Developing Countries: a Panel Data Study." International Journal of Emerging Markets 12, no. 4 (2017): 658-82. https://doi.org/10.1108/ijoem-102014-0169

[17] Kyophilavong, Phouphet, and $\mathrm{OH}$ Jeong-Soo. "Does ASEAN-Korea FTA Reduce Poverty in Laos? The Roles of FDI and Trade Facilitation" Journal of social development in Africa 5 (2014): 50-57. https://doi.org/10.22610/jsds.v5i2.805

[18] ASEANStatsDataPortal, Flows of Inward Foreign Direct Investment (FDI) into ASEAN by Source Country (in million US\$), https://data.aseanstats.org/fdi-by-hosts-and-sources

[19] Department of Statistics Singapore, Singapore's Direct Investment Abroad (Stock As At Year-End), Annual,https://www.tablebuilder.singstat.gov.sg/pu blicfacing/selectVariables.action

[20] United Nations indicators, TARGET1.1, https://unstats.un.org/sdgs/indicators/database/

[21] United Nations indicators, TARGET1.2, https://unstats.un.org/sdgs/indicators/database/

[22] IAI \& NDG Division, ASEAN Economic Community Department, ASEAN Secretariat," ASEAN Integration and Narrowing the Development Gap"

[23] Ministry of Foreign Affairs Singapore, "ASEAN Overview",https://www.mfa.gov.sg/SINGAPORES -FOREIGN-POLICY/InternationalOrganisations/ASEAN

[24] ASEANStatsDataPortal, Gross domestic product (GDP) per capita in ASEAN, at current prices (nominal), in US dollars (Annually), https://data.aseanstats.org/indicator/AST.STC.TBL. 7 